\title{
KINERJA GROUND HANDLING MENDUKUNG OPERASIONAL BANDAR UDARA
}

\author{
Yulianti Keke $^{1}$,Primadi Candra Susanto ${ }^{2}$ \\ 1,2 Institut Transportasi dan Logistik TRISAKTI, Jakarta, Indonesia \\ e-mail: yuliakeke@gmail.com,primstrisakti@gmail.com,
}

\begin{abstract}
This study aims to determine: The effect of leadership style on the performance of civil servants at Lanud Haluoleo, Kendari, Southeast Sulawesi. Effect of work discipline on employee performance. Effect of leadership style and work discipline on the performance of civil servants. This study was categorized as a quantitative associative causal study with an instrument in the form of a questionnaire. The population in this study were 81 civil servants from Lanud Haluoleo. Sampling technique using Sampling Proposal. The sample in this study was to take a population or as many as 81 samples. Data collection using questionnaires and interviews. Test the validity of the instrument using Confirmatory Factor Analysis, while the reliability test uses Cronbach Alpha. The measuring instrument proved to be valid and reliable for research instruments. Multiple regression analysis is used to test the hypothesis of this study.

The results of the study found that: Leadership Style had a positive and significant effect on employee performance by 0.313 with a significance of 0.01 . The contribution of leadership style to employee performance is $9.7 \%$. Work discipline has a significant positive effect on the performance of civil servants Lanud Haluoleo of 0.282 with a significance of 0.05 . The contribution of work discipline to employee performance is $7.5 \%$. Leadership style and work discipline have a positive and significant effect on the performance of civil servants Lanud Haluoleo at ( $\beta$ ) 0.484 with a significance of 0.05 . Contribution of leadership style and work discipline to explain the performance of civil servants at Haluoleo Airport at $14.1 \%$.

Keyword : Leadership Style, Work Discipline, Employee Performance.
\end{abstract}




\section{PENDAHULUAN}

Dalam satu fase penerbangan dari bandar udara asal menuju bandar udara tujuan, pesawat udara akan mengalami beberapa fase terbang mulai dari persiapan terbang, taxi-out dari apron, lepas landas (take-off), terbang menanjak (climb), terbang jelajah (cruise), terbang menurun (descent), approach dan taxiin di bandar udara tujuan. Selain fase tersebut di atas, karena alasan tertentu, pesawat udara akan melewati fase holding sebelum pesawat akan melakukan pendaratan. Setiap fase penerbangan akan memberikan kontribusi terhadap konsumsi bahan bakar pesawat udara. Oleh karena itu sangat penting bagi maskapai penerbangan agar dapat mengoperasikan pesawat udara tepat waktu sesuai dengan jadwal yang telah ditentukan, agar konsumsi bahan bakar pesawat udara tidak menimbulkan penambahan pada biaya operasional penerbangan. Namun, dengan semakin meningkatnya permintaan terhadap transportasi udara, terjadinya keterlambatan penerbangan pada bandara-bandara sibuk dapat menjadi rutinitas sehari-hari. Keterlambatan dalam kegiatan penerbangan terbagi kedalam dua jenis, yaitu ground delay, yang terjadi mulai dari gate sebelum keberangkatan hingga taxiing menuju landas pacu. Keterlambatan yang terjadi pada saat taxiing ini sering disebabkan oleh kepadatan lalu lintas penerbangan dimana jumlah keberangkatan melebihi kapasitas
Bandar udara. Jenis keterlambatan selanjutnya yaitu airborne delay yang terjadi pada saat pesawat udara memasuki fase holding sebelum pesawat udara melakukan pendaratan.

Industri air cargo memiliki peran penting di dalam perdagangan internasional. Barangbarang yang memerlukan kecepatan waktu dan pengeliminasian pergudangan sangat bergantung kepada moda transportasi ini. Jenis air cargo yang heterogenos, bergantung kepada bentuk, ukuran, kepadatan, dan berat berpengaruh terhadap penempatannya di dalam pesawat dan penanganan darat (ground handling).

Ground handling berasal dari kata "ground" dan "handling". Ground artinya darat atau di darat, yang dalam hal ini di bandara (airport). Handling berasal dari kata hand atau handle yang artinya tangan atau tangani. To handle berarti menangani, melakukan suatu pekerjaan tertentu dengan penuh kesadaran. Handling berarti penanganan atau pelayanan (service to service, sehingga pada banyak kesempatan kita sering menjumpai pemakaian kata "Ground Service". Dan dalam banyak kasus, kita juga sering menemukan kata “Ground Operation”. Baik "Ground Handling”, "Ground Service", "Ground Operation", maupun "Airport Service", pada dasarnya mengandung maksud dan pengertian yang sama, yaitu merujuk kepada "suatu aktivitas 
perusahaan penerbangan yang berkaitan dengan penanganan atau pelayanan terhadap para penumpang berikut bagasinya, kargo, pos, peralatan pembantu pergerakan pesawat di darat dan pesawat terbang itu sendiri selama berada di bandara, untuk keberangkatan (departure) maupun untuk kedatangan atau ketibaan (arrival)". Secara sederhana, "Ground Handling" atau "Tata Operasi Darat" adalah pengetahuan dan keterampilan tentang penanganan pesawat di apron, penanganan penumpang dan bagasinya di terminal dan kargo, serta pos di cargo area.

Dalam dunia penerbangan, dikenal adanya tiga tahap utama dalam pelayanan, yaitu:

1. Pre flight service, artinya kegiatan penanganan terhadap penumpang dan pesawat sebelum keberangkatan (di bandara asal / origin station).

2. In flight service, berarti kegiatan pelayanan terhadap penumpang selama didalam pesawat.

3. Post flight service, adalah kegiatan penanganan terhadap penumpang, kargo, dan pesawat setelah penerbangan atau kedatangan (di Bandara tujuan/destination).

Tujuan Ground Handling mempunyai tujuan atau target-target/sasaran-sasaran yang ingin dicapai, yakni:

\section{Flight Safety}

\section{On Time Performance}

\section{Customer Satisfaction}

\section{Reliability}

Pelayanan Penumpang, syarat pengangkutan penumpang beserta bagasi yang dibawa telah diatur dalam Konvensi Warsawa, yang tertuang dalam bentuk naskah The IATA General Condition of Carriage.Condition of Contract adalah naskah kontrak antara penumpang dengan perusahaan penerbangan. Kewajiban perusahaan penerbangan adalah menyangkut dan melayani penumpang sesuai kontrak atau perjanjian (berupa tiket) dengan sebaikbaiknya. Secara umum, penumpang dapat dikategorikan menjadi tiga jenis, yaitu penumpang biasa, penumpang khusus, dan penumpang bermasalah. Dan terdapat tiga kategori penumpang yang memerlukan penanganan secara khusus, diantaranyafamily and group traveler, religious traveler, dan passenger with medical problem.

Orientasi Pelayanan Terhadap Airlines:

1. Melancarkan dan memindahkan penumpang, bagasi, kargo dan pos dari 
suatu tempat ketempat yang lain dengan mengharapkan pendapatan.

2. Menjamin keamanan dan keselamatan penumpang, bagasi, kargo, dan pos yang diangkut.

3. Mengembangkan dan mempercepat komunikasi dan perhubungan antar suatu daerah, baik nasional maupun internasional.

4. Memberikan keuntungan dari sisi politik ekonomi, sosial, budaya dan faktor keamanan suatu barang.

Obyek yang ditangani oleh Ground Staff pada intinya, meliputi : penumpang, barang bawaan penumpang , Cargo, pos,. Sebagai sebuah proses penanganan, maka muncul istilah : Passenger Handling, Baggage Handling, Cargo. Dimana baik ruang lingkup maupun obyek kegiatan tersebut harus mengacu kepada aturan yang telah ditetapkan oleh "IATA Airport Handlng Manual, IATA AHM 1998 sebanyak 14 section, IATA AHM 2004 sebanyak 8 section. IATA AHM termasuk di dalamnya SGHA (perjanjian kerjasama perusahaan penerbangan dan perusahaan Ground Handling untuk mendefinisikan cost tanpa melupakan kenyamanan penumpang.

Tujuan dari penelitian ini adalah untuk memberikan gambaran kepada pembaca tentang kinerja ground handling dalam rangka mendukung kegiatan operasional Bandar Udara.

\section{LANDASAN TEORI}

Kinerja menurut Alma Buchari (2007), "Kinerja seseorang merupakan kombinasi dari kemampuan, usaha dan kesempatan yang dapat dinilai dari hasil kerjanya" Menurut Subagja (2005) : " Performance is definied as the records of outcomes produced on a spesified job function or activity during a specified time period ". Kinerja menurut Anwar Prabu Mangkunegara (2006), kinerja (prestasi kerja) adalah hasil kerja secara kualitas dan kuantitas yang dicapai oleh seseorang pegawai dalam melaksanakan tugasnya sesuai dengan tanggung jawab yang diberikan kepadanya.

Menurut Rivai dan Basri (2005) kinerja adalah kesediaan seseorang atau kelompok orang untuk melakukan suatu kegiatan dan menyempurnakannya sesuai dengan tanggung jawabnya dengan hasil yang seperti diharapkan. Pengertian kinerja lainnya dikemukakan oleh Payaman Simanjuntak (2005) yang mengemukakan kinerja adalah tingkat pencapaian hasil atas pelaksanaan tugas tertentu. Kinerja perusahaan adalah tingkat pencapaian hasil dalam rangka mewujudkan tujuan perusahaan.

Freddy Rangkuti (2003), sebagai berikut kualitas layanan merupakan penyampaian jasa yang akan melebihi tingkat kepentingan 
konsumen. Jelas ditekankan dalam definisi tersebut bahwa pemberian jasa atau layanan yang berkualitas tinggi adalah yang memenuhi dan bahkan melebihi kebutuhan dan harapan pelanggan. Persepsi tentang kualitas memang cenderung relatif atau dengan kata lain, mengarah kepada subyektifitas penilai, salah satu contohnya: kebutuhan dan harapan satu pelanggan dengan pelanggan lainnya akan berbeda.

Menurut Majid dan Warpani (2009), Ground Handling adalah suatu aktifitas perusahaan penerbangan yang berkaitan dengan penanganan atau pelayanan terhadap para penumpang berikut bagasinya, kargo, pos, peralatan pergerakan pesawat di darat dan pesawat terbang itu sendiri selama berada di bandar udara, baik keberangkatan departure) maupun untuk kedatangan (arrival). Tujuan dan sasaran-sasaran yang ingin dicapai oleh ground handling adalah sebagai berikut: flight safety, on time performance, customer satisfaction dan reliability. Target flight safety dan OTP sangat dirasakan oleh pihak eksternal (pax) dan pihak internal (perusahaan), sementara tujuan customer satisfaction akan sangat dirasakan oleh pihak eksternal dan tujuan efisiensi pasti akan sangat dirasakan manfaatnya oleh pihak internal. Pada hakekatnya ada tiga komponen utama penyelenggaraan bisnis penerbangan dapat berjalan, khususnya ground handling. Ketiga komponen tersebut adalah perusahaan penerbangan (airlines), berikut sarana angkutnya berupa pesawat terbang (aircraft), bandar udara (airport) dan konsumen (dalam hal ini passanger dan shipper). Ketiga komponen utama ini secara sendiri-sendiri memiliki keterkaitan dengan unit-sub unit lainnya yang memiliki peran tidak kecil. Pelayanan ground handling sudah dimulai ketika pesawat akan merapat ke parking stand. Pada saat itu petugas marshalling sudah mulai memandu pesawat untuk parkir, sementara yang memasang wheel chock adalah petugas ground handling. Kegiatan pelayanan ground handling selesai ketika pesawat sudah didorong mundur, aircraft towing tractor sudah lepas dan pesawat mulai taxi.

Berdasarkan Peraturan Menteri Perhubungan Nomor: PM 49 Tahun 2012 tentang Standar Pelayanan Penumpang Kelas Ekonomi Angkutan Udara Niaga Berjadwal Dalam Negeri, terdapat tiga tahap utama dalam pelayanan, yaitu pre fligh service, inflight service dan post flight service. Pre flight service artinya kegiatan penanganan terhadap penumpang dan pesawat sebelum keberangkatan (dibandara asal), inflight service berarti kegiatan pelayanan terhadap penumpang selama di dalam pesawat. Sementara itu, post flight service adalah kegiatan penanganan terhadap penumpang, kargo dan pesawat setelah 
penerbangan atau kedatangan (di bandara tujuan). Dari ketiga pelayanan diatas, dapat menghasilkan tujuan ground handling, yaitu flight safety, on time performance, customer satisfaction dan efficiency. Area pelayanan ground handling, yaitu terminal area, cargo area dan appron area. Ketiga tempat tersebut saling berkaitan antara satu dengan yang lainnya. Karena setiap bagasi yang dibawa penumpang melewati ketiga tempat tersebut.

Menurut Peraturan Menteri Perhubungan Tahun 2010 Tentang Tatanan Kebandarudaraan Nasional, Bandar Udara adalah kawasan di daratan atau perairan dengan batasan-batasan tertentu yang digunakan sebagai tempat pesawat udara mendarat dan lepas landas, naik turun penumpang, bongkar muat barang, dan tempat perpindahan intra dan moda transportasi, yang dilengkapi dengan fasilitas keselamatan dan keamanan penerbangan, serta fasilitas pokok dan penunjang lainnya, yang terdiri atas Bandar Udara umum dan Bandar Udara khusus, yang selanjutnya Bandar Udara umum disebut dengan Bandar Udara.

Bandar udara adalah wilayah tertentu di darat atau air (termasuk bangunan, instalasi, dan peralatan) yang dimaksudkan untuk digunakan, baik seluruhnya atau sebagian, untuk kedatangan, keberangkatan, dan pergerakan darat pesawat. Secara umum, pengembangan Bandar udara sering disebut dengan master plan (rencana induk) Bandar udara. Master plan Bandar udara merupakan dokumen yang menunjukkan perkembangan bandara agar dapat sesuai dengan kebutuhan dimasa depan. Kerumitan dan ukuran dari master plan bandara bergantung pada ukuran bandara itu sendiri.

Sedangkan dalam Document 4444 Air Traffic Management, ICAO (International Civil Aviation Organization), Bandar Udara didefinisikan sebagai suatu tempat atau daerah, di darat atau di perairan dengan batas-batas tertentu, termasuk bangunan dan instalasi, yang dibangun untuk keperluan pergerakan pesawat terbang lepas landas (take-off), pendaratan (landing), atau pergerakan di permukaan (taxiing). Menurut Annex 9, Facilitation, Bab I, Definisi dan Penerapan, Bandar Udara Internasional adalah : "Any Airport designated by the Contracting State in whose territory it is situated as an airport of entry and departure for international air traffic, where are formalities incident to customs, immigration, public health, animal, and plant quarantine and similar procedures are carried out."

Dalam terjemahan bebasnya berarti : Setiap bandar udara yang berada di wilayah negara anggota dan ditetapkan oleh negara yang bersangkutan sebagai bandar udara bagi kedatangan dan keberangkatan penerbangan internasional, dimana ketentuan-ketentuan tentang kepabeanan, imigrasi, kesehatan, karantina hewan dan tumbuh-tumbuhan serta prosedur sejenis dilaksanakan. 
Runway atau landasan pacu adalah fasilitas bandara yang sangat penting untuk mendarat dan lepas landasnya pesawat. Landas pacu adalah area persegi dipermukaan bandara yang disiapkan untuk take off dan landing pesawat, tanpa landas pacu yang dierncanakan dan dikelola dengan baik, pesawat tidak akan dapat menggunakan bandara. Dalam merancang landas pacu (runway) diatur secara ketat mengenai panjang, lebar, orientasi (arah), konfigurasi, kemiringan/kelandaian, dan ketebalan perkerasan runway. Runway difasilitasi oleh system marka (marking), system pencahayaan (lighting), dan ramburambu (signs) untuk mengidentifikasi runway dan memberikan panduan arah kepada pilot saat pesawat berjalan, lepas landas, dan ancang-ancang pendaratan dan mendarat.

Elemen dasar runway meliputi perkerasan, bahu runway, runway strip, blast pad (buangan semburan mesin), runway and safety area (RESA), stopway dan clearway. Fasilitas runway ini mempunyai beberapa bagian yang masingmasingnya mempunyai persyaratan tersendiri (Sartono, dkk, 2016). Taxiway adalah jalur yang dirancang dipermukaan bandara yang digunakan sebagai jalur keluar pesawat dari runway menuju apron. Berikut adalah penjelasan bagian pada taxiway (Sartono, dkk, 2016).

Aircraft stand taxilane, bagian dari a. apron yang ditujukan sebagai taxiway dan bertujuan untuk menyediakan akses menuju tempat parkir pesawat. b. Apron taxiway, bagian dari sistem taxiway yang bertujuan untuk menyediakan rute pesawat menyebrangi apron. c. Rapid exit taxiway, sebuah jalur yang menghubungkan antara taxiway dan runway dengan sudut tajam dan dirancang untuk keluar bagi pesawat yang mendarat dengan kecepatan yang lebih tinggi.

Apron adalah suatu area di bandara yang bertujuan untuk mengakomodasi pesawat untuk menaik-turunkan penumpang, barang, kargo, mengisi bahan bakar, parkir dan perawatan pesawat. Apron harus dirancang dengan sesuai kebutuhan dan karakteristik terminal, beberapa pertimbangannya adalah sebagai berikut (Sartono, dkk, 2016). a. Menyediakan jarak paling pendek antara landasan pacu dan tempat pesawat berhenti. b. Memberikan keleluasaan pergerakan pesawat untuk melakukan manuver sehingga mengurangi tundaan. c. Memberikan cadangan cukup daerah untuk pengembangan. d. Memberikan efisiensi, keamanan secara maksimum. e. Meminimalkan dampak lingkungan. 
Fasilitas bangunan terminal adalah salah satu bangunan yang sangat penting karena sesuai fungsinya untuk melayani semua kegiatan yang dilakukan oleh penumpang dari mulai keberangkatan sampai kedatangan. Berikut bagian pada fasilitas keberangkatan dan kedatangan (Sartono, dkk, 2016). Dari sisi Fasilitas keberangkatan yang pertama, Check in counter adalah fasilitas pengurusan tiket keberangkatan pesawat dan Check in area adalah area yang dibutuhkan untuk menampung penumpang yang mengurus tiket, luasannya berpengaruh pada jumlah penumpang pada suatu bandara. Dan terakhir, Rambu/marka terminal bandara, fasilitas custom immigration quarantina, ruang tunggu, tempat duduk, fasilitas umum lainnya seperti toilet, telpon, lainya. Sedangkan Fasilitas kedatangan yang pertama, Ruang kedatangan adalah ruangan yang digunakan untuk menampung penumpang yang turun dari pesawat setelah melakukan perjalanan. dan Beggage conveyor belt adalah fasilitas yang digunakan untuk melayani pengambilan begasi penumpang, panjang dan jenisnya dipengaruhi oleh jumlah penumpang. terakhir Rambu/marka terminal bandara, fasilitas custom immigration quarantine, ruang tunggu, tempat duduk, fasilitas umum lainnya seperti toilet, telpon, lainnya.
Bangunan Terminal Barang (Kargo) Fasilitas bangunan terminal barang adalah bangunan yang digunakan untuk kegiatan bongkar muat barang udara yang dilayani oleh Bandar udara tersebut. Luasannya dipengaruhi oleh berat dan volume kargo pada waktu sibuk yang dilayani oleh bandara tersebut. Fasilitas-fasilitas seperti gudang, gedung operasi dan tempat parkir merupakan fasilitas yang standar dalam bangunan terminal barang (Sartono, dkk.2016).

Bangunan Operasi Sartono, dkk (2016) menyatakan bahwa fasilitas bangunan operasi adalah sebagai berikut. a. Gedung operasional, antara lain menara control, stasiun meteorologi, gedung very high frequency omnidirectional range (VOR), dan gedung distance measuring equipment (DME). b. Bangunan teknik penunjang, seperti power house dan stasiun bahan bakar, aspek kelistrikan, dan jaminan penunjang sampai pergerakan pesawat. c. Bangunan administrasi, dan umum, seperti kantor bandara, kantor keamanan dan rumah dinas bandara, serta bangunan kantin dan lain sebagainya.

Bidang Pelayanan Operasi Bandar Udara dalam melaksanakan tugasnya dibagi 
menjadi 3 (tiga) Divisi yang masing-masing mempunyai tugas sebagai berikut :

1. Divisi Pelayanan Sisi Udara. Mempunyai tugas menyiapkan dan melaksanakan kegiatan pelayanan sisi udara, meliputi pengaturan dan penempatan parkir pesawat udara serta ketertiban lalu lintas orang, kendaraan, dan peralatan di sisi udara;

2. Divisi Pelayanan Terminal dan Sisi Darat. Mempunyai tugas menyiapkan dan melaksanakan kegiatan penyiapan penerbangan, pelayanan informasi untuk pemakaian jasa bandar udara, pengaturan izin masuk (Pas bandar udara) serta operasi pelayanan sisi darat;

3. Divisi Pelayanan Sistem Informasi Operasi Bandar Udara. Mempunyai tugas menyiapkan dan melaksanakan kegiatan serta pengolahan data penerbangan dan sistem informasi bandar udara.

\section{METODE PENELITIAN}

Metode penelitian yang digunakan adalah metode penelitian kualitatif melalui studi pustaka, literatur, dan pengamatan umum di lapangan. Adapun waktu penelitian dilaksanakan pada tahun 2019, dengan mengambil menganalisa kinerja Ground Handling di Bandar Udara. Dalam studi tersebut akan dibahas tentang pelayanan yang diberikan oleh Ground Handling dalam rangka mendukung kegiatan operasional Bandar Udara.

Teknik Analisis Data Teknik analisis data dilakukan dengan metode deskriptif kualitatif. Metode dan analisis data bertujuan untuk menyederhanakan seluruh data yang telah terkumpul, disajikan secara sistematik, kemudian diolah dan dianalisis.

\section{PEMBAHASAN}

Pelayanan Bagasi Penumpang definisi bagasi secara singkat adalah barang yang dibawa penumpang didalam penerbangan. Secara lebih luas, bagasi adalah bawaan, artikel, harta benda, dan barang-barang milik pribadi penumpang, baik bagasi tercatat, bagasi kabin maupun bagasi tak tercatat yang diizinkan oleh perusahaan penerbangan untuk dapat diangkut di pesawat udara guna keperluan pribadi untuk dipakai atau digunakan oleh penumpang selama melakukan perjalanan atau ditempat tujuan penumpang beraktivitas.

Berdasarkan pengertian bagasi tersebut, dapat dibagi kedalam tiga (3) golongan utama, yaitu :

1. checked baggage, adalah bagasi terdaftar dan dimuat di tempat khusus barang didalam pesawat yang disebut cargo compartment. 
2. unchecked baggage, adalah barang bawaan yang dibawa sendiri kedalam kabin pesawat.

3. unaccompanied

baggage/luggage,adalah barang bawaan penumpang yang dikirim atau diangkut sebagai kargo.

Semua bagasi penumpang tanpa kecuali harus ditimbang. Jumlah bagasi penumpang yang boleh dibawa didalam penerbangan dibatasi jumlahnya sesuai dengan kelas pelayanan. Ada dua konsep pengaturan membawa bagasi penumpang pada penerbangan internasional, yaitu konsep berdasarkan berat atau weight concept dan konsep berdasarkan jumlah koli atau piece concept.

Secara umum, prosedur penanganan bagasi dalam dunia penerbangan sudah diatur sedemikian rupa sehingga tercipta standardisasi yang sama antara satu airline lainnya. Maksud prosedur tersebut adalah tata cara, aturan, atau urutan proses pengiriman bagasi atau penerimaan bagasi dari stasiun keberangkatan hingga stasiun tujuan. Urutan tersebut dimulai dari pemeriksaan bagasi oleh security check, lalu melakukan pembayaran apabila bagasi melebihi ketentuan, kemudian bagasi dibawa dan dimasukan kedalam pesawat (proses loading), dan bagasi di stasiun tujuan diturunkan atau dibongkar (proses unloading) oleh petugas. Penanganan bagasi meliputi :

1. Baggage handling, yang mencakup menangani bagasi di baggage sorting area dan menyiapkan pengiriman / pengantaran kedalam pesawat.

2. Menetapkan berat bagasi yang disusun.

3. Menurunkan atau mengeluarkan bagasi dari taktor / gerobak / kendaraan, membongkar dan atau mengosongkan tempat bagasi, memeriksa bagasi yang datang.

4. Memisahkan bagasi transfer dan menyimpan bagasi transfer dalam suatu periode sampai waktu keberangkatan / pengiriman.

5. Menyediakan atau mengatur pengangkutan bagasi ke sorting area dari departemen yang akan menerima.

6. Menangani bagasi awak pesawat (crew baggage) sesuai dengan kesepakatan bersama.

Pada umumnya kasus penyimpanganpenyimpangan yang timbul dari hasil pelayanan bagasi akan tampak pada saat penumpang tiba di stasiun tujuan akhir atau pada saat post-flight service. Kasus-kasus yang timbul di area kedatangan atau arrival hall dapat dikelompokan sebagai berikut :

1. Bagasi hancur atau rusak (damage), 
2. Penemuan bagasi (bagasi tak bertuan),

3. Bagasi hilang atau berkurang (lost),

4. Keterlambatan bagasi (delayed),

5. Penyimpangan penempatan bagasi.

Terjadinya kerusakan, kekurangan, kehilangan bagasi, termasuk keterlambatan penyerahan bagasi yang diakibatkan oleh miss routing (salah alamat), yakni tidak sesuai dengan tujuan, banyak biaya dan kerugian bagi penumpang maupun pihak perusahaan penerbangan.

Penanganan Pesawat di Apron Area, ada dua cara penanganan pesawat di Bandar udara, yaitu Turn arround arrangement dan transit arrangement. Turn arround arrangement adalah penanganan bagi pesawat yang mendarat di kota tujuan akhir (final destination) sedangkan transit arrangement adalah penanganan bagi pesawat yang mendarat di kota persinggahan atau transit. Penanganan pesawat di Bandar udara, baikturn around maupun transit arrangement menganut sistem yang sama. Perbedaannya terletak pada lama waktu penanganannya. Penanganan transit arrangement biasanya lebih pendek dibanding turn around arrangement. Prosedur penanganan pesawat dibandar udara antara satu jenis pesawat dengan jenis pesawat yang lain tidak sama. Namun, secara umum lama waktu yang diperlukan untuk keperluan/kegiatan turnaround arrangement adalah 40 Menit - 1 Jam.
Untuk memperlancar pekerjaan di bagian ramp handling diperlukan beberapa peralatan pembantu pergerakan pesawat, penumpang, dan kargo selama di darat (Bandar udara). Peralatan - peralatan bantu yang dipersiapkan untuk mendukung kebutuhan pesawat udara selama pesawat tersebut berada di darat, baik pada saat keberangkatan, kedatangan, maupun transit dikenal dengan istilah GSE (Ground Support Equipment). Setiap perusahaan mempunyai standar masingmasing, atau dapat juga airlines sebagai konsumen menentukan service able dan service level yang harus dicapai oleh perusahaan ground handling. Service ability dan service level sangat berpengaruh terhadap tingkat pelayanan di apron.

Weight and Balance pada pesawat terbang. Perhitungan weight and balance sebuah pesawat yang dilakukan secara akurat sesuai standar yang ditetapkan, merupakan prioritas utama terhadap keamanan pesawat dan keselamatan penumpang selama melakukan penerbangan. Beban pesawat tergantung pada berat pesawat dan jumlah muatan, karena segala bentuk muatan yang menyebabkan bertambahnya total weight adalah suatu hal yang harus dihindari selama penerbangan. 
Bagaimanapun pilot tidak bisa menghindari penambahan beban/berat pada pesawat. Penerbangan menjadi mudah jika pesawat dalam keadaan ringan, namun sebaliknya akan berbahaya jika muatan pesawat terlalu berat.

$$
\text { Maximum (Design) Take-Off }
$$

Weight adalah berat maksimum yang diizinkan sebelum melakukan lepas landas. Perhitungan berat maksimum ini dipengaruhi oleh kondisi atmosfer tertentu dan panjang lintasannya, serta kemampuan struktur pesawat tersebut menahan muatan yang akan diangkut. Sedangkan Maximum (Design) Landing Weight adalah berat maksimum yang diizinkan bagi pesawat yang akan mendarat. Bagian bawah pesawat berfungsi untuk melindungi semaksimal mungkin struktur pesawat saat touch down sehingga harus dicegah muatan barang yang berlebihan.

Salah satu sektor jasa jasa yang perlu melakukan meningkatkan kualitas pelayanan adalah sektor Ground Handling yaitu pelayanan darat terhadap pesawat udara, penumpang, bagasi, kargo dan pos. Perusahaan Ground Handling mempunyai strategi khusus yang berbeda dari perusahaan lain dalam upaya peningkatan pelayanan salah satunya adalah pelayanan yang diberikan kepada penumpang. Tidak sedikit perusahaan penerbangan yang memberikan kepercayaannya dalam mengurus pelayanannya di Bandar Udara dan Aircraft Ground Handling.

\section{KESIMPULAN}

Ground handling sangat berperan penting dalam memberikan penanganandan pelayanan penumpang di area terminal bandara, mulai dari proses penumpang tiba di bandara keberangkatan dan menjalani proses check-in sampai dengan penumpang berada di dalam pesawat dan penumpang tiba di bandara tujuan dan mengambil barang bawaan atau bagasi. Ground handling berperan dalam meningkatkan mutu pelayanan sebagai pembuktian kinerja para petugas yang berada terminal bandara dan para petugas sebuah perusahaan maskapai penerbangan di mata para penumpang.

Keberhasilan pelayanan yang diberikan perusahaan ketika penumpang datang ke bandara sampai dengan kembali datang akan menjadi penilaian dan kenangan tersendiri bagi para penumpang yang pernah mendapat pelayanan yg mempermudah dan mempercepat proses keberangkatan para penumpang saat di bandara. Setiap penumpang mengharapkan kelancaran dalam melakukan prosedur-prosedur yang telah menjadi ketetapan pada setiap perusahaan penerbangan sebelum keberangkatan. Oleh sebab itu Petugas Ground Handling harus selalu siap dalam memberikan penanganan dan pelayanan kepada penumpang 
yang membutuhkan bantuan yang berkaitan dengan keberangkatannya. Dimana Setiap penumpang mengharapkan pelayanan yang dapat mempermudah dan mempercepat proses perjalanan yang akan dijalani para penumpang. Kelancaran seluruh proses keberangkatan yang baik dan benar yang dirasakan bagi para penumpang yang akan naik pesawat sangatlah penting, baik bagi para penumpang itu sendiri maupun bagi perusahaan penerbangan sehingga dapat terciptanya kenyamanan dan kepuasan dari para penumpang yg diberikan oleh perusahaan penerbangan tersebut.

Pelayanan yang sesuai dengan harapan penumpang akan menunjukkan kinerja yang baik bagi suatu perusahaan penerbangan sehingga akan meningkatkan citra perusahaan di mata masyarakat yang tentunya akan memberikan keuntungan bagi perusahaan. Dalam mencapai tujuan tersebut diperlukan sumber daya manusia yang ahli di bidangnya yang dapat bekerjasama satu sama lain demi mencapai tujuan yang diharapkan. Disamping itu perlu diadakan pembagian kerja yang baik antar unit Ground Handling serta pelatihanpelatihan yang berhubungan dengan penanganan penumpang untuk menghasilkan sumber daya manusia yang berkualitas dan betul-betul dapat menguasai pekerjaanya dan hal-hal lain yang terkait

\section{DAFTAR PUSTAKA}

Alma, Buchari. (2007). Delivery Quality Service Balancing Customer Perception and Expetations. Newyork: The Free Press. Angkasa Pura II. (2014), Statistik Angkutan Udara 2013. Laporan PT. Angkasa Pura II. Tangerang, Banten.

Anwar, P. (2006). Evaluasi Kinerja Sumber Daya Manusia. Jakarta: Refika Aditama.

Peraturan Menteri Perhubungan Nomor: PM 49 Tahun 2012 tentang Standar Pelayanan Penumpang Kelas Ekonomi Angkutan Udara Niaga Berjadwal Dalam Negeri, Kementerian Perhubungan Jakarta.

Rangkuti \& Freddy. (2003). Measuring Customer Satisfaction: Teknik Mengukur dan Strategi Meningkatkan Kepuasan Pelanggan. Jakarta: PT. Gramedia Pustaka Utama.

Rivai, Veithzal \& Ahmad, F. (2005).

Performance Appraisal. Jakarta: PT Raja Grafindo Persada.

Simanjuntak, Payaman, J. (2005). Manajemen dan Evaluasi Kerja. Jakarta: Lembaga Penerbit FEUI.

Subagya. (2005). Psikologi Pelayanan Dalam Industri Jasa, Jakarta: Gramedia.

Undang-Undang No.1 Tahun 2009, Kementerian Perhubungan, Jakarta. 
